\title{
Sequential genital infections with herpes simplex virus types 1 and 2
}

\author{
A M Al SAMARAi,* A A Shareef,* G R KINGHORN, $\dagger$ C W POTTER \\ From the *Departments of Microbiology, Anatomy, and Cell Biology, Basrah Medical College, Basrah, Iraq, \\ and the Departments of $\uparrow$ Genitourinary Medicine and $\ddagger$ Virology, Sheffield University Medical School, Sheffield
}

SUMMARY Herpes simplex virus (HSV) types 1 and 2, typed by an enzyme linked immunosorbent assay (ELISA), were isolated at different clinical episodes from five people with genital herpes. This finding has important implications for assessing resistance to antiviral drugs in therapeutic studies.

Herpes simplex virus (HSV) infections are increasingly common throughout the world. Primary genital infections may be caused by types 1 or 2 , although HSV 2 infections are most likely to cause genital recurrences. Previous studies have shown that concurrent oral and genital infections with an identical HSV strain may occur in the same person and that prior oral herpes caused by HSV 1 fails to prevent subsequent genital infection with HSV 2.1-8 Nevertheless, exogenous reinfection with either HSV 1 or HSV 2 in patients with recurrent genital herpes is considered to be uncommon. ${ }^{9}$

In this study we report sequential genital infections with HSV 1 and HSV 2 in five patients.

\section{Patients and methods}

The patients reported here were derived from large groups of patients attending the department of genitourinary medicine, Sheffield, who participated in therapeutic trials of antiviral treatment for genital herpes during 1982-5. During those studies swabs from genital lesions were sent routinely for culture of HSV in tissue, using methods described previously. ${ }^{10}$ All isolates of HSV were identified as being HSV 1 or HSV 2 by an enzyme linked immunosorbent assay (ELISA) using either a monoclonal antibody technique, which was described by Nilheden et al ${ }^{11}$ and standardised in our laboratory (Al Samarai, unpublished observation), or a polyclonal antibody technique reported previously. ${ }^{12}$

To differentiate between primary and non-primary infection we performed microneutralisation tests on

\footnotetext{
Address for reprints: Dr G $R$ Kinghorn, Department of Genitourinary Medicine, Royal Hallamshire Hospital, Glossop Road, Sheffield S10 2JF
}

Accepted for publication 1 July 1988 serum samples from patients. ${ }^{13}$ Samples taken at the acute phase showed titres of less than $1 / 10$ for both virus types were considered to indicate primary infection.

\section{Case reports (table)}

\section{CASE 1}

A white man aged 24 first presented with herpetiform ulcers on the penile shaft in January 1984 and was seen two months later when HSV 2 was isolated from subpreputial lesions. He subsequently entered a therapeutic study of topical acyclovir cream and attended with culture proved recurrences at either penile site on four separate occasions in January to May 1985. Thereafter his clinical recurrences were completely suppressed by continuous treatment with oral acyclovir.

All of his HSV isolates were typed using the same monoclonal antibody technique. All were HSV 2 except that obtained during a recurrence in March 1985, which was HSV 1.

\section{CASE 2}

A white homosexual man aged 37 presented with a three year history of recurrent genital herpes with 15 attacks in the preceding year. In July 1983 HSV 1 was isolated from a single perianal herpetiform ulcer. Two months later he presented with several herpetiform papules, vesicles, and ulcers in the natal cleft. The isolate from these lesions was found to be HSV 2. His clinical recurrences were subsequently completely suppressed by continuous oral acyclovir treatment.

\section{CASE 3}

A white woman aged 27 who was separated from her husband presented in August 1983 with a three year history of genital herpes that recurred monthly. At 
Table Enzyme linked immunosorbence assay (ELISA) absorbance of clinical isolates of herpes simplex virus (HSV) from five patients

\begin{tabular}{|c|c|c|c|c|c|c|}
\hline \multirow[b]{2}{*}{ Case No } & \multirow[b]{2}{*}{ Site of lesion } & \multirow[b]{2}{*}{ Date of isolation } & \multicolumn{3}{|c|}{ Mean (SD) absorbance in ELISA using: } & \multirow[b]{2}{*}{ HSV type } \\
\hline & & & $B I C l$ & Polyclonal & $C 4 D 5$ & \\
\hline 1 & $\begin{array}{l}\text { Subpreputial skin } \\
\text { Subpreputial skin } \\
\text { Penile shaft } \\
\text { Subpreputial skin } \\
\text { Subpreputial skin }\end{array}$ & $\begin{array}{l}150384 \\
300185 \\
060385 \\
080385 \\
290485\end{array}$ & $\begin{array}{l}0.05(0.01) \\
0.05(0.01) \\
0.05(0.01) \\
0.30(0.01) \\
0.01(0.00)\end{array}$ & & $\begin{array}{l}0.24(0.00) \\
1.10(0.08) \\
0.30(0.05) \\
0.75(0.06) \\
0.22(0.03)\end{array}$ & $\begin{array}{l}2 \\
2 \\
2 \\
1 \\
2\end{array}$ \\
\hline 2 & $\begin{array}{l}\text { Perianal skin } \\
\text { Natal cleft }\end{array}$ & $\begin{array}{l}190783 \\
010983\end{array}$ & $\begin{array}{l}0.31(0.00) \\
0.00(0.00)\end{array}$ & & $\begin{array}{l}0.37(0.00) \\
0.24(0.01)\end{array}$ & $\begin{array}{l}1 \\
2\end{array}$ \\
\hline 3 & $\begin{array}{l}\text { Vulva } \\
\text { Vulva } \\
\text { Vulva }\end{array}$ & $\begin{array}{lll}12 & 1184 \\
171284 \\
150185\end{array}$ & $\begin{array}{l}0.89(0.01) \\
0.68(0.07) \\
0.03(0.01)\end{array}$ & & $\begin{array}{l}1.30(0.02) \\
0.95(0.04) \\
0.26(0.01)\end{array}$ & $\begin{array}{l}1 \\
1 \\
2\end{array}$ \\
\hline 4 & $\begin{array}{l}\text { Vulva } \\
\text { Vulva } \\
\text { Vulva }\end{array}$ & $\begin{array}{l}030583 \\
161184 \\
281085\end{array}$ & $\begin{array}{l}0.06(0.01) \\
0.78(0.01) \\
0.59(0.09)\end{array}$ & & $\begin{array}{l}0.22(0.03) \\
0.49(0.01) \\
0.14(0.01)\end{array}$ & $\begin{array}{l}2 \\
1 \\
1\end{array}$ \\
\hline 5 & $\begin{array}{l}\text { Perineal skin } \\
\text { Labial skin }\end{array}$ & $\begin{array}{l}280283 \\
261084\end{array}$ & $0.64(0.04)$ & $0.39(0.04)^{*}$ & $0.39(0.05)$ & $\begin{array}{l}2 \\
1\end{array}$ \\
\hline
\end{tabular}

B1Cl = HSV 1 type specific monoclonal antibody.

C4D5 = HSV 1 and HSV 2 type common monoclonal antibody.

$* 1 / 11$ index in ELISA using polyclonal antibody ( $\geqslant 0.8$ indicates HSV $1, \leqslant 0.7$ indicates HSV 2$)$

that time she had six herpetiform ulcers on the right labium, from which no virus was isolated. She presented again in November 1984 with a single right labial ulcer from which HSV 1 was isolated. The same virus type was also isolated from a lesion at a similar site one month later.

Thereafter the patient started to receive oral acyclovir suppressive treatment. Despite this, she attended in January 1985 with a group of vesicles on the right labium and ulcers at the fourchette and perineum from which HSV 2 was isolated. Her lesions have since been suppressed completely by increasing the daily dose of acyclovir from $800 \mathrm{mg}$ to $1600 \mathrm{mg}$.

CASE 4

A single white woman aged 22 presented in May 1984 with dysuria and painful vulval sores affecting the labia minora. Serological studies indicated that she had a primary infection, and HSV 2 was isolated from her lesions.

Her first clinical recurrence occurred in October 1984 , and she attended again one month later with a second recurrence when a vesicle and papule were present on the left labium majus. Two weeks after that lesion had healed, another developed on the right labium majus. HSV 1 was isolated from both of these recurrent lesions.

CASE 5

A single woman aged 19 of mixed ethnic origin presented in February 1983 with primary genital herpes. Examination showed bilateral inguinal lymphadenopathy and perineal ulcers from which HSV 2, typed by polyclonal antibody ELISA, was isolated. She subsequently returned in November 1983 with her first clinical recurrence, which was not virologically confirmed.

In October 1984, she presented again with a papule on the left labium from which HSV 1, typed by monoclonal antibody ELISA, was isolated.

\section{Discussion}

Few reports of sequential genital infections caused by different HSV types have been published. Buchman $e t$ al showed differing HSV 2 isolates by restriction endonuclease fingerprinting of viral DNA from two patients. ${ }^{14}$ Their findings do not necessarily confirm that exogenous reinfection occurred, because HSV 2 strains may undergo genetic variation in the course of adapting in a new person. ${ }^{15}$ More recently both HSV 1 and HSV 2 genital infections in two women have been reported. ${ }^{116}$ Our cases were similar and also show that genital reinfection may occur in patients of either sex and that either HSV 1 or HSV 2 may be the initial virus type.

Because of the differing sensitivities to antiviral drugs of HSV 1 and HSV 2 isolates from the same person we advocate that the type and strain of HSV isolate should be continuously monitored in therapeutic studies. This would avoid erroneous conclusions being drawn about the effect of treatment on the development of resistance of HSV to antiviral drugs.

\section{References}

1 Gerson M, Portnoy J, Hamelin C. Consecutive infections with herpes simplex virus types 1 and 2 within a three week period. J Infect Dis 1984;149:655. 
2 Whitney JE, Skinner GRB, Buchan A. Acquisition of type 1 herpes simplex vulvitis within a monagamous relationship. British Journal of Venereal Diseases 1978;54:121-3.

3 Juel-Jensen BE, Maccallum FO. Herpes simplex, varicella, and zoster: clinical manifestations and treatment. Philadelphia: Lippicott, 1972.

4 Evrard JR. Orogenital transmission of herpes simplex type 1. Obstet Gynecol 1974;44:593-5.

5 Chang TW. Herpetic angina following orogenital exposure. Journal of the American Venereal Disease Association 1975;1:163-4.

6 Reeves WC, Corey L, Adams HG, Vontver LA, Holmes KK. Risk of recurrence after first episodes of genital herpes. $N$ Engl J Med 1981;305:315-9.

7 Embil JA, Manuel FA, McFarlane ES. Concurrent oral and genital infection with an identical strain of herpes simplex virus type 1. Restriction endonuclease analysis. Sex Transm Dis 1981;8:70-2.

8 Peutherer JF, Smith IW, Robertson DH. Genital infection with herpes simplex virus type $1 . J$ Infect 1982;4:33-5.

9 Schmidt OW, Fife KH, Corey L. Reinfection is an uncommon occurrence in patients with asymptomatic recurrent genital herpes. J Infect Dis 1984;149:645-6.

10 Barton IG, Kinghorn GR, Najem S, Al-Omar LS, Potter CW.
Incidence of herpes simplex virus types 1 and 2 isolated in patients with herpes genitalis in Sheffield. British Journal of Venereal Diseases 1982;58:44-7.

11 Nilheden E, Jeanson S, Vahine A. Typing of herpes simplex virus by an enzyme-linked immunosorbent assay with monoclonal antibodies. J Clin Microbiol 1983;17:677-80.

12 Vestergaard B, Jensen $O$. Diagnosis and typing of herpes simplex virus in clinical specimens by the enzyme-linked immunosorbent assay (ELISA). In: Nahmias AJ, Dowdle WR, Schinazi RF, eds. The human herpes viruses. New York: Elsevier, 1981:391-4.

13 Rawls WE, Iwamoto K, Adams E, Melick JL. Measurement of antibodies to herpes simplex virus type 1 and 2 in human sera. $J$ Immunol 1970;104:599-606.

14 Buchman TG, Roizman B, Nahmias AJ. Demonstration of exogenous genital reinfection with herpes simplex virus type 2 by restriction endonuclease fingerprinting of viral DNA. $J$ Infect Dis 1979;140:295-304.

15 Smith IW, Maitland NJ, Peutherer JF, Robertson DH. Restriction enzyme analyses of herpes virus-2 DNA. Lancet 1981;ii:1424.

16 Kit S, Trkula D, Qavi H, et al. Sequential genital infections by herpes simplex viruses types 1 and 2: restriction nuclease analysis of viruses from recurrent infections. Sex Transm Dis 1982;10:67-71. 